JAHRBUCH DER ÖSTERREICHISCHEN BYZANTINISTIK, 53. Band/2003, 1-21

(C) 2003 by Österreichische Akademie der Wissenschaften, Wien

ANASTASIA D. VAKALOUDI / THESSALONIKI

\title{
INFLUENCES OF THE RELIGIOUS SYNCRETISM IN THE EARLY BYZANTINE SOCIETY*
}

In the early Byzantine period sources we often see repetitions of famous religious contests of the past, concerning miracles and magic ${ }^{1}$. Other times religious confrontations between Christians and gentiles are blended with accusations about exercising magic. Sometimes, in early Christian hagiography, this confrontation turns to be only accusations about exercising magic from the one or the other side ${ }^{2}$. In these cases, the dogmatic confrontations between Christian and infidel priests turn into contests where they demonstrate their supernatural powers. These confrontations often take place in front of kings. The basic elements are that the infidel priests work always with the power of the demons and that the "canonically religious" men always win.

The repetition of the ancient contests of miracles and magic helps also the Christians to identify their holy men with the ancient miracle-workers, and in this way, to present them as the successors of the ancient holy men. Thus they can strengthen the angle that Christianism is the only acceptable religion and endowed with the power to create miracles, whereas the others are motivated by the evil demons and consequently their achievements can be explained as black magic, sorcery, and illusion.

Finally, through these contests we can have an idea of how much the religious syncretism, the admixture of religions that had started at the Hellenistic age and came to its utmost point at the second and third centuries $\mathrm{AD}^{3}$, had shaped the eastern religions and how much magical beliefs had dominated this world.

In the first place the Christians wanted to prove that the power of the Jewish God (Father of Christ) was the only true and miraculous power in

* The subject has been presented in a paper at the XIV Hellenic Historical Congress of the Hellenic Historical Association (Thessaloniki, 30, 31 May and 1 June 2003).

${ }^{1}$ A. Kazhdan, Holy and Unholy Miracle Workers, in: Byzantine Magic, ed. H. Maguine. Washington, D.C. 1995, 73-82.

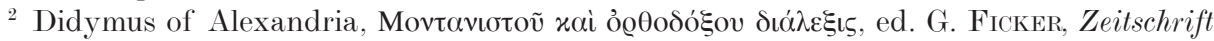
für Kirchengeschichte 24 (1905) 455, 13-14.

${ }^{3}$ L. Gernet - A. Boulanger, Le génie grec dans la religion (L'évolution de l'humanité 1,11). Paris 1932, 466 . 
comparison with the one of the pagan gods that were still powerful and influential at the early Byzantine period. An effective way of achieving this was to repeat the most known religious magic contest, the one between the powerful Egyptian magicians Iannes - Iambres and the Hebrew Moses (attested not in the Old Testament but in the Jewish apocrypha from the second c. B. C. $)^{4}$. They contested in front of the Pharaoh in miracle-working, which is always the area of the magicians and the holy men; to these contests belong the subjugation of poisonous snakes and the domination on earth, water, air and fire ${ }^{5}$. People believed that the adepts of the laws of the universe could dominate the elements that the sublunary or cosmic area consisted of. These elements were earth, water, air, fire; they were made of mindless nature and subjected to vitiation ${ }^{6}$. Based on this contingency,

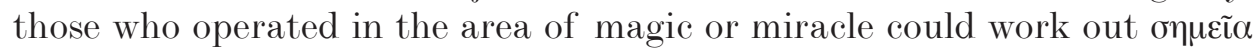
xai $\tau \dot{\varepsilon} \varrho \alpha \tau \alpha$ (signs and wonders) ${ }^{7}$. Signs were called all the miracles that took place on the air ${ }^{8}$. Wonders were called all the miracles that took place on the earth as supernatural phenomena?

If one takes in mind, a) that some gentiles accused Moses as a magician and thought of his teachings to his fellow countrymen, a theory about the angels and their similar cult, as magic ${ }^{10}$,

b) the Hebraic teachings, that the angels are responsible for every element in nature such as crystal, hail, frost, cool, winds, clouds, snow, ice,

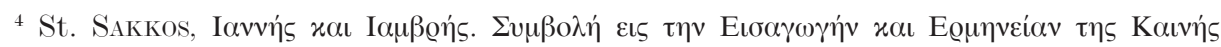

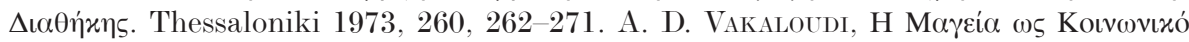

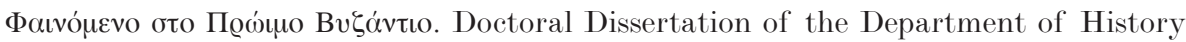
and Archaeology of the Aristotelian University of Thessaloniki. Athens 2001, 52.

${ }^{5}$ Macarius Alexandrinus, De patientia et discretione, $P G$ 34, 868C. Pseudo-Macarius/ Symeon $=$ Makarios/Symeon, Reden und Briefe. Die Sammlung I des Vaticanus Graecus 694 (B), ed. H. Berthold. 1. Teil. Einleitung und Tabellen, die Logoi B 2-29 (GCS).

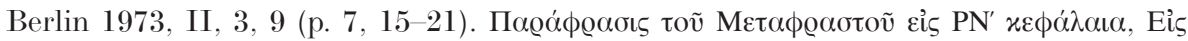

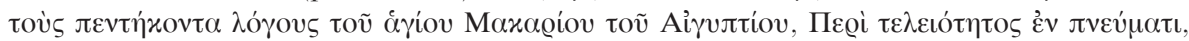

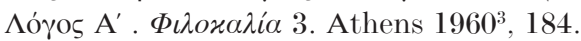

${ }^{6}$ Eusebe of Caesarea, Tricennatsrede an Constantin, ed. I. A. Heikel, Eusebius Werke I (GCS 7). Leipzig 1902, 11, 13. Michael Psellus, Summaria et brevis dogmatum chaldaicorum expositio, PG 122, 1149-1152; Idem, Hypotyposis, in G. Kroll, De Oraculis Chaldaicis (Breslauer Philologische Abhandlungen VI, 1). Breslau 1894, 75.

7 Jean Chrysostome, Pour le deuxième jour de la Grande Semaine sur le psaume 5, sur les Actes: "Hommes d' Israel" et sur l'évangile: "Voici l'Agneau de Dieu", ed. J. Liébaert, Deux homélies anoméennes pour l' Octave de Pâques (SC 146). Paris 1969, 21, 306310 .

8 John Lydus, Liber de mensibus, ed. R. WüNsch, editio stereotypa editionis primae 1898, Stuttgart 1967, 2. 171.

9 John Lydus, Liber de mensibus, 2. 171.

${ }^{10}$ Origène, Contre Celse, ed. M. Borret, t. I. Livres I et II (SC 132). Paris 1967, I. 26. 
sounds, clap, shaft, cold, heat, every season of the year, but also the animals, the plants, the humans and anything else that exists on earth ${ }^{11}$, then one can track down the unchallengeable belief that some men, called either magicians or miracle workers, had the acquiescence of these spirits (and through them of God himself) ${ }^{12}$ to control their corresponding cosmic elements as they wished.

According to a conception which had its roots in the Hellenistic age and had been developed during the Christian centuries, these powerful "Philosopher-magicians" were studying the supernatural forces and because of this knowledge they managed to control them ${ }^{13}$. The Christian writers developed this perception from their own point of view. At first they wanted to point that the ancient pious and virtuous Jews, the ones that God had chosen for a holy mission, were endowed with the miraculous power to contact the spirits and be able to control them or to be clairvoyants. The Jew Joseph for example, the son of Jacob, who had lived in Egypt and could explain the dreams -which means to contact the good intermediate supernatural forces <angels> and learn the will of God, an idea that Plato adopted too with his daemonia, demons ${ }^{14}$ - had proved himself wiser than the astrologists, the diviners, the magicians, the philosophers. The Jew prophet Daniel who had also the ability to explain the dreams, had overpassed the Babylonian sages, astrologists, diviners, magicians, philosophers ${ }^{15}$.

The explaining of dreams was a characteristic of the all-powerful Persian and the Babylonian Magi ${ }^{16}$ but also of the Egyptian magician-priests ${ }^{17}$. However, the Christians wanted to prove that only the ancient holy Jews,

11 Epiphanius of Salamis, De mensuris et ponderibus, $P G$ 43, 276. J. M. Hull, Hellenistic Magic and the Synoptic Tradition. London s.d., p. 38.

${ }^{12}$ Cf. John Chrysostom, In Epistolam ad Ephesios commentarius, cap. IV, Homilia VIII, $P G 62,63$.

${ }^{13}$ John Lydus, Liber de mensibus, 4. 81. Michael Psellus, Expositio in oracula chaldaica, $P G$ 122, 1132. E. R. Dodds, The Greeks and the Irrational. Berkeley and Los Angeles

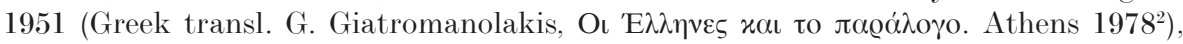
p. 205.

14 Plato, Symposion, text, translation, and commentary, ed. Io. Sykoutris, Athens $1976^{6}$, $202 \mathrm{e}-203 \mathrm{a}$, and n. 2 , p. 138.

15 John Chrysostom, In Epistolam ad Philippenses commentarius, cap. II, Homilia V, PG $62,215-216$.

${ }^{16}$ Hérodote, Histoires, ed. Ph.-E. Legrand, Livre VII, Polymnie. Paris 1951, 19. G. Luck, Arcana Mundi. Magic and the Occult in the Greek and Roman Worlds. A Collection of Ancient Texts Translated, Annotated and Introduced. Baltimore and London 1985, 5-6. H. C. Kee, Medicine, Miracle and Magic in New Testament Times. Cambridge, London 1986; repr. 1987; first paperback ed. 1988, 99.

17 Hérodote, Histoires, ed. Ph.-E. Legrand, Livre II, Euterpe. Paris 1944, 83, n. 1, p. 120. 
the ancestors of Christianism, were using the powers of the good spirits and so they always won, while the others were using the evil spirits, the demons, and so they were unable to overcome them. Consequently the

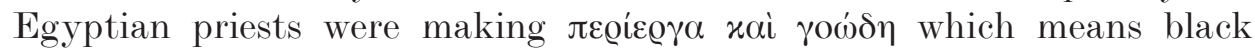
magic and deceiving illusions but the same acts performed by Moses and Aaron were real miracles worked by God ${ }^{18}$. This privilege was claimed afterwards by the Christians while the gentiles and the heretics, like Jews or Gnostics, were being accused of turning to the demons instead of the good spirits ${ }^{19}$.

According to the tradition, many times the Jewish philosopher-magicians - like the famous demons' persecutor Solomon - had the ability of using angels against the demons. In astrology and in theories about spirits the archangels - who sometimes are called gods - and the angels are connected with the stars and the celestial bodies which are their residences ${ }^{20}$. There were special angels who had as a duty to chase the demons to the infernal places (hell). These were the orders of the Angels, the Archangels, the Cheroubim and the Seraphim ${ }^{21}$. Therefore, if someone wished to fight the demons, he had to call these spirits for help $p^{22}$.

The Jews had the fame of being excellent exorcists; according to the testimony of Joseph they carried out successful magical ceremonies by which they averted the demons that caused illnesses, pain and grief to the humans. In these ceremonies they combined herbal medicines with the recitation of magical prayers. These prayers were said to be the prayers that Solomon had written by the inspiration of God himself. With them and by the help of Michael, the most powerful angel, he had dominated and imprisoned the demons ${ }^{23}$.

18 Eustathius von Antiochien, Über die Hexe von Endor, ed. E. Klostermann, Origenes, Eustathius von Antiochien und Gregor von Nyssa über die Hexe von Endor (Kleine Texte für Theologie und Philologie 83). Bonn-Berlin 1912, 9. 27, 27.

19 Epiphanius von Salamis, Ancoratus und Panarion haeresiarum, ed. K. Holl, I, 1-33 (GCS 25). Leipzig 1915, 3. 303, 14-25.

20 Th. Hopfner, Griechisch-Ägyptischer Offenbarungszauber (thereinafter OZ), v. I. Amsterdam 1974 (Impr. $1^{\text {st }}$ ed. Leipzig 1921), \$§ 154, 151.

${ }^{21}$ John Chrysostom, In Epistolam ad Philippenses commentarius, cap. III, Homilia XIII, $P G 62,279$.

${ }^{22}$ Callinicos, Vie d' Hypatios, ed. G. J. M. Bartelink (SC 177). Paris 1971, 28, 14-30, (188-192). K. Preisendanz, Papyri Graecae Magicae (thereinafter PGM), vols. 1-2 Leipzig 1928; 1931. $2^{\text {nd }}$ ed. vols 1-2 Stuttgart 1973/1974, 2: P. 10. Pseudo-Psellus, Le De Daemonibus du Pseudo-Psellos, ed. P. Gautier, REB 38 (1980) 105-194, Text: pp. 133-177; p. 171, 570 - p. 173, 589. HopfNer, OZ I. § 178.

${ }^{23}$ Flavius Josephus, The Jewish Antiquities, Books V-VIII, ed. R. Marcus (Loeb Classical Library). London 1958 ( $3^{\text {d }}$ Impr. $1^{\text {st }}$ ed. 1934), VIII. 46-49. Cf. Preisendanz, PGM. 2: 
Nevertheless, the Christians couldn't allow this reputation of the Jews to be continued. This nation had become the most hateful for Christianism and so the Jewish exorcists had to be proven as despicable magicians. A way of doing this successfully was to mention a relative "indirect" contest, the one that took place between this kind of Jewish magicians and the Apostle Paul, at the time that he was teaching in Ephesos (AD. 54-57). The Jewish exorcists of that time were well informed of Christ's miracles and they were also eyewitnesses of the miracles that Paul had performed in His name in Ephesos. So they dared to add Christ's and Paul's names, among the powerful magic names which they used in their prayers in order to avert a demon from a possessed $\operatorname{man}^{24}$. But it seems that at this time the Jews didn't have the help of the angels they called; the moment they pronounced Christ's and Paul's names, the demon had attacked them, bit them wildly and chased them wounded ${ }^{25}$.

Another aim of the Christian writers was to show that the Christian miracle-workers were the only true successors of the Hebrew prophets, the most respectful and miraculous men in the Jewish religion, who were blessed to speak directly with God and his angels. The Christian holy men had to be shown as the heirs of this divine power and its miraculous emanations. The best way of proving this, was to ascribe to the Christian holy men all the miraculous characteristics of the prophets.

Flying was one of the supernatural powers that the Hebrew prophets had. Elias flew in the sky in a vehicle of fire ${ }^{26}$. However, it must be men-

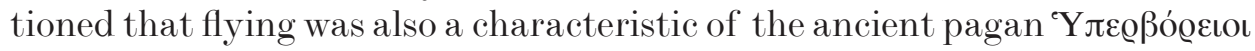
(Hyperboreans lived north from Scythes) miracle-workers and holy men,

P. 17 (Amulet against the evil spirits and illness, 5th or 6th century AD). G. VIKAN, Art, Medicine and Magic in Early Byzantium. DOP 38 (1984) 65-86, pp. 69-70, 80. Supplementum Magicum I, ed. R. W. Daniel - F. Maltomini, Papyrologica Coloniensia, vol. XVII, 1. Köln 1989, 24. fr. B., p. 68 and n. 3.

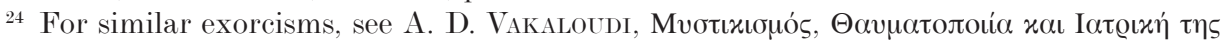

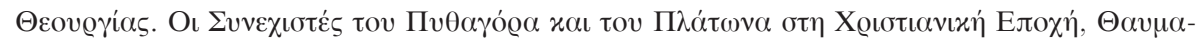

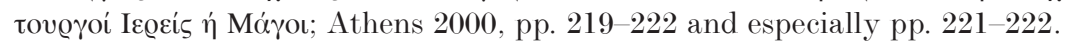

${ }^{25}$ John Chrysostom, Commentarius in Acta Apostolorum, Homilia XLI, PG 60, 288. Idem, Argumentum Epistolae Primae ad Corinthios, $P G$ 61, 11.

${ }^{26}$ Jean Chrysostome, Pour le deuxième jour de la Grande Semaine sur le psaume 5, sur les Actes: "Hommes d'Israel" et sur l'évangile: "Voici l'Agneau de Dieu", 15, 205-220. S. Ephraem Syrus, Sermo in Eliam [BHG 574]: Sermones in Abraham et Isaac, in Basilium Magnum, in Eliam, in: S. Ephraem Syri Opera, Textum syriacum graecum latinum ad fidem codicum ed. S. I. Mercati, t. I, fasc. 1 (Monumenta Biblica et Ecclesiastica 1). Romae 1915, 120-121. p. 222, 477 - p. 223, 484. 
the priests of the god Apollo, like Abaris the student of Pythagoras ${ }^{27}$, or of the ancient Greek miracle-workers and seers, priests of the god Dionysus, like Musaeus. At the early Byzantine period also the Neoplatonic writers attached the ability of flying to their holy men, like Isidorus ${ }^{28}$. According to the Christians, all the idolaters who had this characteristic, were magicians helped in their action by the evil demons. This was proven by a contest about flying, cited in the Byzantine sources, which was held between Christian holy men and a magician. It was the one between the Apostles Paul and Peter and Simon the Magus ${ }^{29}$ in Rome, in front of the emperor Nero. Simon, the founder of Gnosticism, who professed to be the Holy Spirit ${ }^{30}$, wanted to be the very opposite of $\mathrm{Christ}^{31}$, and was proclaimed by his followers as god, announced that he could fly up to the sky in a vehicle of the demons. The Apostles Peter and Paul had blasted him on the earth with an arrow by praying to their God ${ }^{32}$.

Because of the influence, which the magicians exercised upon people, the Christian writers' main interest was to expose them and to show that their intention was to deceive people in any way; one way that the magicians were using, in order to deceive people, was to impress them with "monstrous" illusions and, by this means, to take advantage of them as much as they could. However, the Christian holy men appeared with their superior powers as peoples' saviors and helped them to free themselves from the magicians' deception and exploitation. In this way, by exposing the magicians' illusional arts, they showed people where to turn and ask for help during moments of crisis. Accordingly, at the age of Constantine the

${ }^{27}$ Hérodote, Histoires, ed. Ph.-E. Legrand, Livre IV, Melpomène. Paris 1945, 36. Kosmas of Jerusalem, Ad Carmina S. Gregorii Theologi, PG 38, 347-670. M. P. Nilsson, A History of Greek Religion. Oxford $1949^{2}$ (Greek transl. A. Papathomopoulou, Iotooía tᄁร

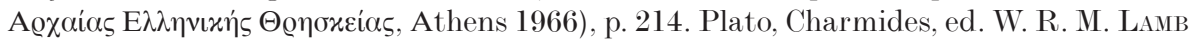
(Loeb Classical Library). London 1964 (2 ${ }^{\text {nd }}$ Impr. of the $1^{\text {st }}$ ed. 1927), n. 3, pp. 58-59.

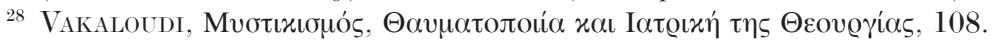

${ }^{29}$ Macarius Alexandrinus, De patientia, $P G$ 34, 868C. Pseudo - Macarius / Symeon =

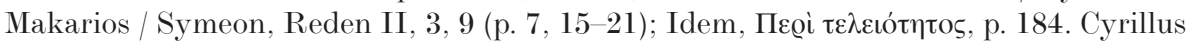
of Jerusalem, Procatechesis, ed. G. K. Reischl, S. patris nostri Cyrilli Hierosolymorum archiepiscopi opera quae supersunt omnia. München 1848, $2^{\text {nd }}$ Impr., Hildesheim 1967, vol. I., 2. p. 2 ; 4, p. 8. John Malalas, Chronographia, ed. L. Dindorf, Bonn 1831, 255, $9-18$.

${ }^{30}$ Cyrillus of Jerusalem, Catechesis XV illumandorum, ed. J. Rupp, S. patris nostri Cyrilli Hierosolymorum archiepiscopi opera quae supersunt omnia. München 1860, $2^{\text {nd }} I m p r$, Hildesheim 1967, vol. II, 5. p. 160.

${ }^{31}$ Cyrillus of Jerusalem, Catechesis XVI illumandorum, ed. J. Rupp, ibidem, vol. II, 6. p. 210.

${ }^{32}$ Cyrillus of Jerusalem, Catechesis XVI illumandorum, 15. p. 176. John Malalas, Chronographia, p. 255, 9-18. 
Great a magician appeared to the army in Cappadocia, presented a flying dragon and persuaded the crowd to sacrifice to it. Agapetos, the Christian bishop of Synaos, appeared, antagonized the magician and proved himself superior to the magician. In a public contest between them, the magician showed the dragon's apparition while the Christian bishop began to recite prayers. As a result, lightning and thunder began to fall, which dissolved the magician's illusion. This incident confirmed the superiority of Christianism and a lot of people was persuaded by it to be baptised ${ }^{33}$.

Another means that the Christian men of the Church were using, in order to present their miraculous men as the successors of the famous holy Jewish men and ancestors of Christ, was to ascribe to them the power of creating fire. This was a tactic that they had adopted from the Jews. The Jewish writers were also ascribing this miraculous characteristic to their holy men. Accordingly, Moses, the one who was allowed to see God in person, had the ability to create fire with the recitation of a prayer. This power was ascribed to him by the Hebrew writer of the first century AD. Artapanos. Moses said a prayer to his God and suddenly a fire was created without any wood or other material ${ }^{34}$.

Then the prophets were endowed with this miraculous power, which they used in order to fight against gods and priests of every polytheistic religion. For example this miracle working was the basic element in the contest between the prophet Elias and the priests of the god Baal ${ }^{35}$ or Beelphegor, Phegor, Bel, or (in Greek) Kronos ${ }^{36}$. Elias managed, with his prayer to his God, to create fire which fell from the sky and fired the altar with his fatling ${ }^{37}$, while the gentile priests - who cut themselves and spilled their blood according to their custom as an offering to their $\operatorname{god}^{38}$ - had failed ${ }^{39}$.

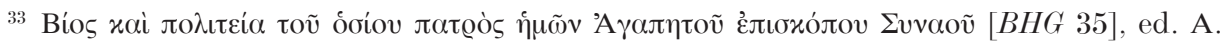
Papadopoulos-Kerameus, Varia Graeca Sacra (Studia Byzantina Lucis ope iterata VI). Leipzig 1975, pp. 114-129, 7, p. 117, 5-15.

34 Eusèbe de Césarée, La préparation évangélique, ed. G. Schroeder - E. Des Places, Livres VIII-IX-X (SC 369). Paris 1991, IX. 27, 21.

${ }_{35}$ John Chrysostom, In Psalmum CV, PG 55, 663-664.

36 John Chrysostom informs us about the contact of the Hebrews with Moabites and their

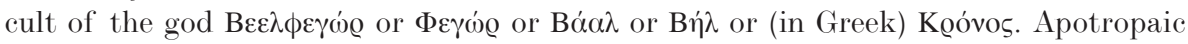

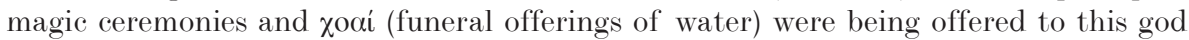
by eastern peoples and the Greeks. The Father concludes by saying that if someone thought of these gods as dead humans, he wouldn't be wrong; see John Chrysostom, In Psalmum CV, 663-664.

37 Jean Chrysostome, Sur le sacerdoce, ed. A.-M. Malingrey (SC 272). Paris 1980, III, 4 $(146,34-45)$.

${ }^{38}$ Eustathius von Antiochien, Über die Hexe von Endor, 8. 26, 6-7.

39 Jean Chrysostome, Sur le psaume II, sur les Actes: "Or le lendemain leurs chefs se réunirent", et sur le boîteux de la Belle Porte, ed. J. LiÉBaERT, Jean Chrysostome, Deux 
In order to accomplish his aim, Elias built an altar with twelve stones - as many as the tribes of Israel (or the Apostles) - and placed a fatling on it, then he made a triple circle with water around it, and after he had said his prayer, fire fell from the sky and burned the fatling. In his prayer to

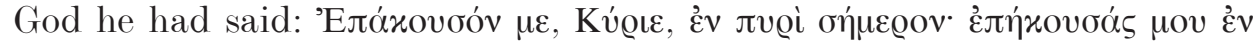

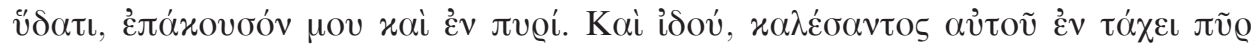

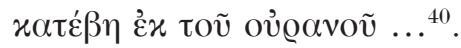

However, it must be mentioned that the magic circle, the purgative ceremonies with water, the magical number three, the use of stones, the sacrifice, were elements which were used by religious men and magicians. The use of these elements had its roots in the eastern belief of the occult$i s m$, an attempt to approach and affect the supernatural forces with material agents, such as sacrifices of animals, use of plants and stones which had a direct connection ("sympathy") with the spirits"1. The Christians were aware of the danger that their religious men could give the impression that they were conducting a magical ceremony, and furthermore that they were magicians who were helped by the demons, instead of miracle-workers acting by the help of God. Thus John Chrysostom - wanting to make the distinction between religious men and magicians - referred to the powers of the prophet to dominate the rain, to command the winds, to throw fire on fatlings, but he made clear that all these happened by the effect of God's grace and permission ${ }^{42}$.

The work of Elias was transferred by the Christian writers to the hands of their holy men. The Christian miracle-workers were using their similar power in order to prove that Christianism was the only true faith against

homélies anoméennes pour l'Octave de Pâques (SC 146). Paris 1969, 2, 31-40. PseudoMacarius/Symeon, Sermon XX., Homélies propres à la collection III (SC 275). Paris 1980, 238, 50-58. Cyrillus of Alexandria, In d. Joannis Evangelium: Accedunt fragmenta varia nec non tractatus ad Tiberium diaconum duo, ed. P. E. Puser, v. III. Oxonii 1868, Impr. Bruxelles 1965², p. 195, 21-22. Kosmas of Jerusalem, Ad Carmina S. Gregorii Theologi, 378.

40 John Chrysostom, In Petrum Apostolum, PG 50, 733. Encomium on ss. Peter and Paul attributed to Severian of Gabala, ed. M. E. FoAt, Encomiastica from the Pierpont Morgan Library, Five Coptic Homilies Attributed to Anastasius of Euchaita, Epiphanius of Salamis, Isaac of Antinoe, Severian of Gabala, and Theopempus of Antioch, translated by P. Chapman - L. Depuydt - M. E. Foat - A. B. Scott - S. E. Thompson, Corpus Scriptorum Christianorum Orientalium, Vol. 545, Scriptores Coptici, t. 48. Lovanii 1993, 128. 94, 19-29. - 130. 95, 14-16.

${ }^{41}$ F. Cumont, Les religions orientales dans le paganisme romain. Conférences faites au collège de France en 1905, Paris 1963 (Impr. $4^{\text {th }}$ ed. 1929), p. 108. DodDs, The Greeks and the Irrational, p. 207.

42 John Chrysostom, In Petrum Apostolum, 734, 736. 
all pagan religions. For example, during the Christian era, Saint Alexander, in a confrontation with a defender of the local gods' cult, turned to the

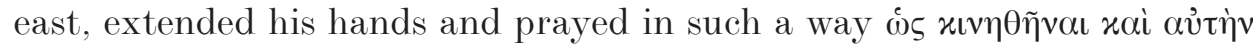

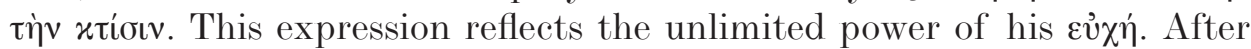
he had said his prayer, fire came from the sky and burnt everything around $\operatorname{him}^{43}$.

However, it must be mentioned that during the Christian age there were also pagan holy men, who lived exactly like the Christians, with prayers, asceticism, and constant contact with the gods, the famous Neoplatonic theurgists, to whom the pagan writers ascribed the same miraculous power of creating fire. For example, exactly the same demonstration of power on fire as the above, was ascribed by Damascius (sixth century AD.) to a gentile "religious man". Asclepiades, the brother of Heraiscus, Neoplatonic philosopher who taught in Alexandria and had studied deeper than his brother the Egyptian mystic knowledge ${ }^{44}$, climbed once the Libanus mountain and from there he threw fire on the soil all over the valley, turning everything into ashes ${ }^{45}$.

The knowledge, which Asclepiades had obtained through his thorough study of the Egyptian mysticism, gave him the power to perform this miracle. If one compares Asclepiades' miracle-working with a fragment from the "Chaldaean Oracles", one will notice an interesting similarity. This fragment reveals to the initiates that, in case they want to invoke Hekate, the goddess will appear in front of them either as a shapeless fire, from which a voice will come out addressing them, or as a huge mass of light, which will explode like a coil around the field, where they stand ${ }^{46}$. As it seems, the miracle-working of Asclepiades focused on the conduction of a magic-mantic rite in the open air, aiming at invoking Hekate and at speaking with her ${ }^{47}$.

Still we can trace a difference here, between a Christian and a gentile miracle-worker. The first worked his miracles for the sake of Christ whereas the other one worked them for his own benefit. This attitude went along with the religious attitude. The Christians asked the supernatural forces

${ }^{43}$ E. De Stoop, Vie d' Alexandre l'Acémète [BHG 47], Patrologia Orientalis, t. 6. Turnhout 1971 (Impr. $^{\text {st }}$ ed. Paris 1909), 13. [27]. p. 667, 9 - [28]. p. 668, 10.

44 The Prosopography of the Later Roman Empire, v. II (AD 395-527), ed. J. R. MARTINDALE, Cambridge, London 1980, p. 158.

45 Damascius, Vitae Isidori reliquiae, ed. C. Zintzen, Hildesheim 1967, (fr.) 166. 10-11.

46 The Chaldean Oracles, ed. R. Majercik, Leiden 1989, fr. 146 (p. 104).

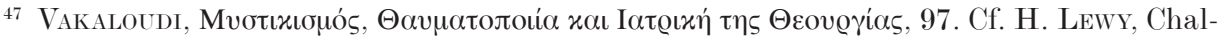
dean Oracles and Theurgy. Mysticism, Magic and Platonism in the Later Roman Empire. Cairo $1956,2^{\text {nd }}$ ed. Paris 1978, pp. 245-246. 
for help. The gentile priests and the magicians believed that they could dominate the supernatural forces, because of their mystic (Egyptian) knowledge, and they commanded them to do as they wished.

Yet the problem of the pagan and the Jewish miracle-workers who created fire remained. Consequently, the Christian holy men had to be proven as their superiors, that is, to have the power to extinguish miraculously the fire that the magicians were creating. An example was traced at the time of Constantine the Great, when another indirect contest took place, which showed the power of the magicians or miracle workers on fire but also on

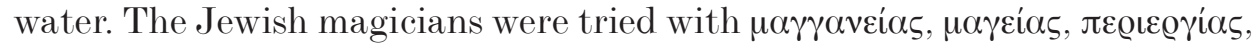
which means magic methods, to quench the fire that some workers were using, in order to build a Christian church in Tiberias. But the Christian priest Joseph ordered to bring to him a basin full of water on which he made the sign of the cross. Then he uttered Christ's name ( $\mu \varepsilon \gamma \alpha \dot{\lambda} \lambda \eta \underline{\eta} \tilde{\eta} \phi \omega v \tilde{\eta})$ - in order to frighten the demons - and he asked that the water would obtain magical powers and nullify the Jewish magic. The recitation of the godly names with a loud voice was a practice held also by magicians, as a method to impose themselves to the demons and frighten them ${ }^{48}$. After he

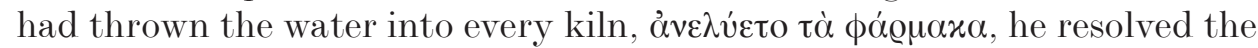
magic and the fire appeared again ${ }^{49}$.

During the Christian age, the Persian court had become a "battlefield" of magic contests between the Christian bishops and the Magi-priests. The cause was, naturally, the influence, which they wanted to exercise upon the Persian king as his counselors, in favour of their religion. Accordingly, a contest of magic, cited by Anastasius I. Sinaïta (sixth century AD.), took place in front of the Persian king Arrinatus. Obviously it concerned the exercise of authority at the royal court; this was proven by the aim of the Persian Magus Oricatus at overcoming the glorious Aphroditianus ( $\theta \alpha u \mu \alpha-$

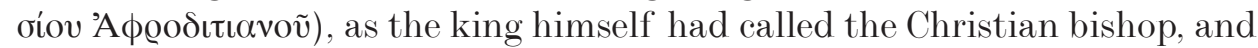
his wish to take up his place ${ }^{50}$. This contest is also very important from another point of view. It constitutes a valuable source about the arts of the famous Chaldaeo-Iranian magic, as it resulted after centuries, when the Chaldaeo-Persians, by the name of Magousaioi, were travelling towards Asia Minor, establishing colonies in the process, after the admixtures and the combinations with different religions, beliefs in angels and demons,

${ }^{48}$ Cf. Lucan, The Civil War, ed. J. D. Duff, Books I-X (Loeb Classical Library). London 1957, VI. 693-694.

49 Epiphanius of Salamis, Panarion, I, 12. 347, $27-348,23$.

${ }^{50}$ Anastasius I. Sinaïta, Das sogenannte Religionsgespräch am Hof der Sasaniden, ed. E. Bratke (TU N. F. IV, 3). Leipzig 1899, p. 22, 4-12. 
superstitious customs, magical practices. Finally, it shows how the Christians were influenced by all these practices and how they used them in their own religion ${ }^{51}$.

As already Iamblich (the introducer of theurgy in Neoplatonism, who lived in the fourth century) had written, the chaldaeo-iranian philosophy, which Oricatus represented, was working on magic about changing the weather phenomena, necromancy, and other kinds of demonic magic or

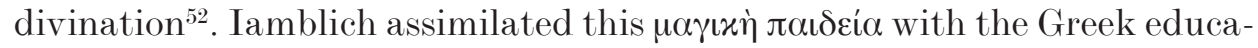
tion $^{53}$. Disposing of both, he himself had became a very prominent orator ${ }^{54}$. The popular faith in the powers of the Chaldaeo-Babylonian magicians was unchallengeable. People believed that these magicians - by using invocations of gods' secret names, all-powerful magical prayers, and magic rites - could work miracles, even resurrections ${ }^{55}$.

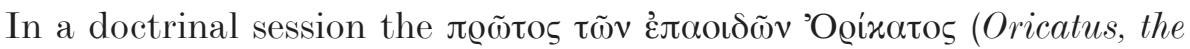
head of Magi) asked for the headmost position because of his ascendancy in miracle working. They all agreed that he should give a real proof of his allegation with signs and wonders ${ }^{56}$. At the beginning he created a hawk of clay and made it fly. The head of the Christians S. Casteleus and the other bishops prayed, and immediately the bird became once again clay and crushed to the ground ${ }^{57}$. Maybe this incident explains very well the fact

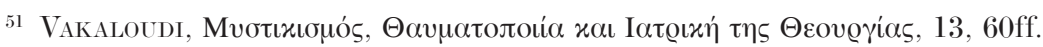

52 J. Bidez - F. Cumont, Les Mages hellénisés, v. II. (Les textes). Paris 1938, fr. B10c, p. 23,

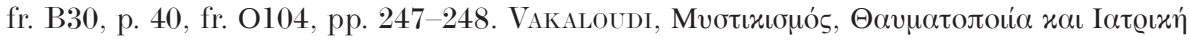

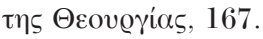

53 This is the reason why, in the sources, the pagans are mentioned as "Greeks". The religious/magic syncretism at the hellenistic age had brought a high estimation about these eastern practices to the Greeks and so they adopted them; see VAKALOUDI, Mvotl-

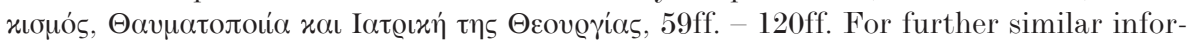

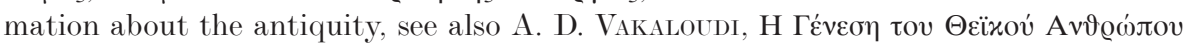

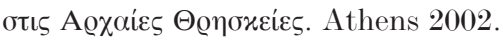

54 Photius, Bibliothèque, v. II. (Codices 84-185), Paris 1960, ed. R. Henry, vols. 1-8, Paris 1959-1977, 94, [75b] (pp. 39-40). J. Bidez - F. Cumont, Les Mages hellénisés,

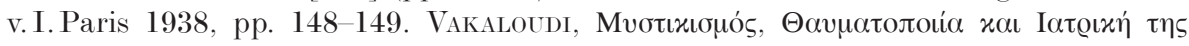

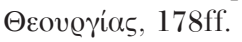

55 Lucian, Philopseudes, ed. C. I Acobitz, Lucianus. Accedunt scholia auctiora et emendatiora, v. III. Hildesheim 1966 (Impr. ed. 1839), 10, 11, 12. Cf. Ephesia Grammata, aus Papyrusrollen, Inschriften, Gemmen u.s.w. gesammelt von K. Wessely. Wien 1886 ,

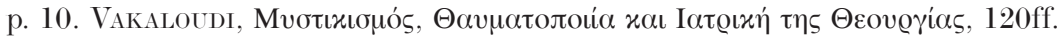

56 Anastasius I. Sinaïta, Das sogenannte Religionsgespräch am Hof der Sasaniden, p. 22, 4-12. - p. 23, 8-21.

57 Ibidem, p. 24. 
that the magicians were based on their illusionistic powers, aiming at tricking people ${ }^{58}$. The bishops revealed the illusion that Oricatus had created, and they showed that his magic was a fraud.

Then Oricatus tried to show his power on water. In order to whiten some Indians and Ethiopians, he took some water from a spring, put it in a silver basin, invoked the spirits, in whom he believed, with a magic prayer (غ̇лooldíav) and poured the water on these persons. At once their body was filled with wounds and they screamed in pain, while he threatened the spirits, which he had summoned, showing his terrible anger against them. The Christian bishops exorcised the victims, they baptized them with an invocation to the Holy Spirit (in order to consecrate the water) and they healed them by converting them to Christianism ${ }^{59}$.

The water had a damaging effect because of the invocation of the gentile gods, as long as they represented the evil spirits, which desired to afflict the humans. On the other hand, it obtained a beneficial virtue after the invocation of the Holy Spirit and Christ's name. Over and above the magician dared to address the spirits menacingly. He believed that he was superior to them and he could control them by force. Therefore he addressed the powers of darkness because, as Iamblich had said, the humans can threaten only the demons; none has the power to threaten the spirits of good. Moreover only the Egyptians were invoking the demons. The Chaldeans exercised theurgy, that is the contact with the good spirits ${ }^{60}$. Thus, what we observe here is an attestation of the religious syncretism $^{61}$.

One of the most characteristic demonstrations of a Persian Magus (and also a man who was engaged in the arts of black magic) was to be able to summon the spirits of the dead. Accordingly, the magician Oricatus went beyond any limit in his attempt to show his powers, and dared to call a

58 This fact had been mentioned by many Christian churchmen, who warned the people to be aware of the magicians' deceitful miracles; see Didymus of Alexandria, Expositio in Psalmos, 63, Psalmus LXII, PG 39, 1433B. Jean d'Apamée, Dialogues et traités, ed. R. Lavenant (SC 311). Paris 1984, VI. 115, 109-119 (syr. 70-81). Cyrillus of Alexandria, In d. Joannis Evangelium, Accedunt fragmenta varia nec non tractatus ad Tiberium diaconum duo, ed. P. E. Pusey, v. III, Oxonii 1868, Impr. Bruxelles $1965^{2}$, p. 195, 5-12. Pseudo-Eusebius of Alexandria, Sermones, Sermo XXII, "De astronomis", $P G 8^{1}$, $453 \mathrm{C}-456 \mathrm{D}$.

${ }^{59}$ Anastasius I. Sinaïta, Das sogenannte Religionsgespräch am Hof der Sasaniden, p. 24.

${ }^{60}$ Jamblique, Les mystères d'Égypte, ed. E. Des Places, Paris 1966, VI. 7, 249. H. P.

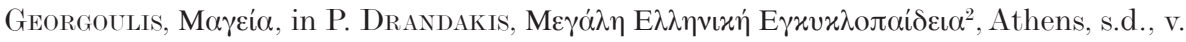
XXII, pp. 412-414, 413.

${ }^{61}$ Gernet - Boulanger, Le génie grec dans la religion, L'évolution de l'humanité, p. 466. 
dead priest from netherworld. The method that he used by lighting up a big fire, offering veals, holding @óßjovs xa@vivas and calling the supernatural forces ${ }^{62}$, corresponds to the description of the Persian magic fire-worship that Persians pretended to have inherited from Zoroaster. It is described as a mystic cult that was based on the principle of the decans ${ }^{63}$ with avestic $^{64}$ hymns, with the existence of fire and sacrifice, and sacred fascicles of sticks with which the faithful "bewitched"

In my opinion, the element of the sticks was bacchic. The faithfuls of Bacchus - a god who had died, went to the underworld and then was resurrected - held torches and sticks crowned with ivy and leaves of the vineyard, that had a pinecone on the top, the so-called $\theta v^{\circ} \sigma_{0}{ }^{66}{ }^{6}$. This element was also Egyptian ${ }^{67}$. Obviously the Magousaioi (the admixture of Chaldeans/ Babylonians/Medoi/Persians) colonists of Lydia, Anatolia and Near East had transferred and developed sorcery in their colonies, along with the fire-worship and the figure of Zoroaster as an astrologist and a prophet. As it seems, they had also combined the fire-worship ceremonies with the local cults of Dionysus-Sabasius and other deities ${ }^{68}$. This religious syncretism is attested also by Oricatus himself, when he refers to Hera as one of the deities whom he worships ${ }^{69}$.

62 Anastasius I. Sinaïta, Das sogenannte Religionsgespräch am Hof der Sasaniden, p. 25.

63 Basic astrological deities that lived in the stars and were attached to the Zodiac, see

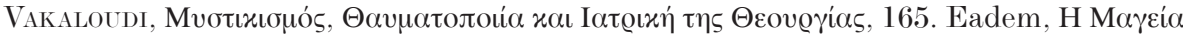

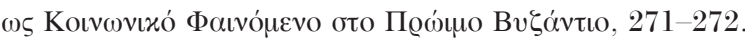

${ }^{64}$ Coming from Avesta, the sacred book of the Persians; see Vakaloudi, Mvotıxıouós,

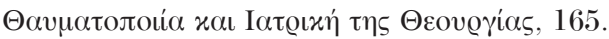

65 Bidez - Cumont, Les Mages hellénisés, v. II, fr. D12, p. 86. VaKaloudi, Mvotıxıouós,

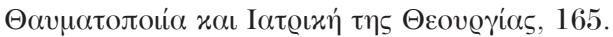

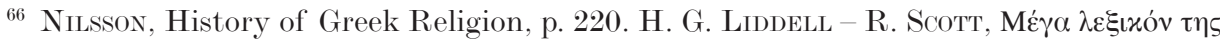

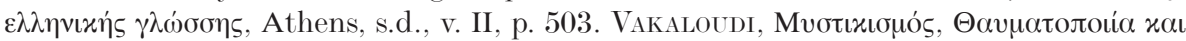

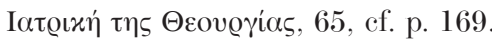

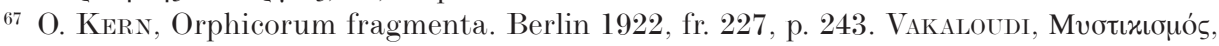

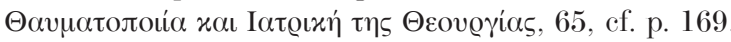

68 Bidez - Cumont, Les Mages hellénisés, v. I, pp. 5-6; Dionysus-Sabasius, an old thracophrygian mystic god, who was born by Jupiter and Persephone or Jupiter and Gaia, had been identified during the hellenistic age (by a bold etymological combination) with "Jahwé Zebaoth" the god of the heavenly army in the Bible. Sabaoth = Sabasius was worshiped as the all-powerful and holy Master of the Universe; see John Lydus, Liber de mensibus, IV. 51, 52. Cumont, Les religions orientales dans le paganisme romain,

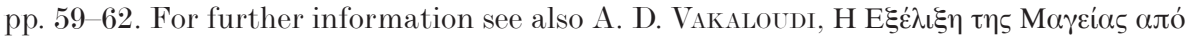

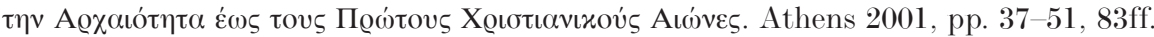

69 Anastasius I. Sinaïta, Das sogenannte Religionsgespräch am Hof der Sasaniden, pp. 26, 29 . 


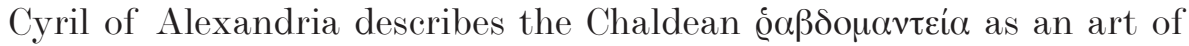

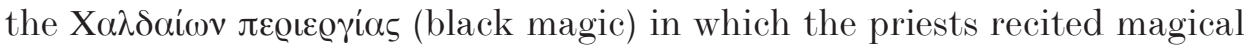
prayers in front of two standing sticks. With the invocation of the demons, the sticks bowed and then they turned back to their place. According to the declination that they had during their fall, the magicians could guess the future. During the process they were in a state of "enthusiasm", of madness, as if the deity had entered into them ${ }^{70}$.

Perhaps in the case of Oricatus, the magician adapts the ceremony of the mantic demonic gathering to his purpose, which is to bring a dead from the netherworld. In addition, what Oricatus was conducting, was a kind of necromancy ${ }^{71}$. So there is a connection between his aim and the demonic kind of divination, which justifies the adopting of this practice. The ghost that came from the netherworld confessed being a demon and not the spirit of the dead priest. He said that he was forced by the magical ceremonies of Oricatus to appear on the earth and to deceive the session. The Christians annihilated the demon with the exorcism of blowing ${ }^{72}$.

The Christian miracle-workers had adopted many of the superstitious methods that the ancient Hebrews used in order to fight against demons. Blowing on the face of someone was also an old traditional Jewish practice. Whoever wanted to exorcise the evil spirits which brought sicknesses, sorrow and every disaster to the humans, exercised this practice along with the recitation of magical prayers ${ }^{73}$. I think that the blowing was based on the creation of man by God. God had blown and His Spirit had entered into the humans. Thenceforth the blowing had the same function as the spittle $^{74}$; it controlled the demons ${ }^{75}$ and at the same time it reflected the

${ }^{70}$ Cyrillus of Alexandria, In XII prophetas post pontanum et aubertum, ed. P. E. Puser, Oxonii 1868, $2^{\text {nd }}$ ed. Bruxelles 1965, v. I, pp. 107-108, 10.

${ }^{71}$ Pseudoclementina, PG 2, cap. 27, col. 492-493. C. H. Kraeling, Was Jesus Accused of Necromancy? Journal of Biblical Literature 59, Part 1 (March 1940) 147-157, p. 156. Luck, Arcana Mundi. Magic and the Occult in the Greek and Roman Worlds, p. 34.

72 Anastasius I. Sinaïta, Das sogenannte Religionsgespräch am Hof der Sasaniden, pp. 25-26, 4.

${ }^{73}$ Cyrillus of Alexandria, In XII prophetas v. II, p. 36, 3-5. - p. 37, 1-5.

${ }^{74}$ About the role of the spittle in the ancient Egyptian mythology see G. PINch, Magic in Ancient Egypt. Austin 1994, 24. Also about the spittle see E. Rohde, Der griechische Roman und seine Vorläufer. Leipzig 1914, 266, n. 4. Ph. Koukoules, Bvלavtıvõv ßíos

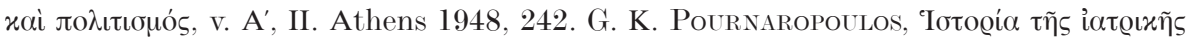

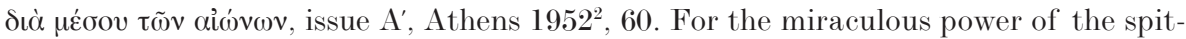
tle in Christianity, see John Chrysostom, Commentarius in sanctum Ioannem Apostolum et Evangelistam, Homilia LVII, PG 59, 311.

75 John Chrysostom, Commentarius in sanctum Ioannem Apostolum et Evangelistam, Homilia LVII, 311. Basilii aliorumque scholia in s. Gregorii orationes, $P G 36,907 \mathrm{~B}-\mathrm{C}$. 
power of life. Therefore it obtained creative power and also gave out something of the holy person that practiced $\mathrm{it}^{76}$.

The most powerful demonstration of a Persian Magus, but also of a man who was involved in the arts of black magic or of a holy man and a miracle-worker, either Christian or pagan (as the famous pagan "saint and god" Apollonius of Tyana, who lived in the first century AD. ${ }^{77}$ ), was the resurrection of the dead. This was also an inheritance from the famous ancient magicians or miracle-workers, as the Egyptians and the Jews, of whom the Persian Magi and the Christian holy men alleged to be the successors. The Egyptian magician-priests, who possessed magical formulae, chests full of magical books (the well known magical papyri) and herbs for charming the humans, were capable of doing very much harm; to bewitch people by spitting them on the face and make them live only during the night while during the day they would lie like dead; to send human souls to netherworld and imprison them there while their bodies would lie on the earth like dead. But for all these bad magic consequences the Egyptians had also antidotes which reversed the situation back to normal ${ }^{78}$.

On the other hand the fame of the Hebrews as powerful magicians is well known and for this reason the magical papyri often recommend the magicians to use the Hebraic language when they call the spirits ${ }^{79}$. The greatest contribution of Judaism into magic is the name of the one God. Its interpretations IA, IAO, ADONAI and JAHWEH are very much in use in magical formulae ${ }^{80}$. Thanks to the knowledge of this name and the teach-

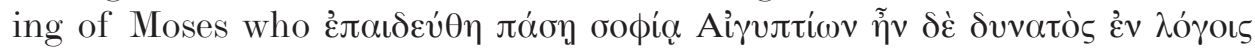

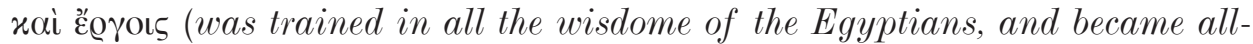
powerful both in words and actions) ${ }^{81}$ but also the names of the famous demons' persecutor Solomon ${ }^{82}$, of the Chaldean astrologist Abraham and the

${ }^{76}$ John Chrysostom, Commentarius in sanctum Ioannem Apostolum et Evangelistam, Homilia LVII, 311.

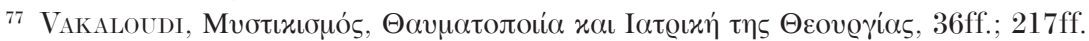

${ }^{78}$ Photius, Bibliothèque, v. II. (Codices 84-185), 166, [109b], (p. 143). - [110a-b], (pp. 144145). Roнde, Der griechische Roman und seine Vorläufer, p. 266ff.

${ }^{79}$ W. M. Brashear - A. Búlow-J Jcobsen, Magica varia. Papyrologica Bruxellensia. Études de papyrologie et éditions de sources 25, Bruxelles 1991, 22.

${ }^{80}$ M. P. Nilssson, Greek Piety. Oxford 1948, 174. A. D. Nock, Greek Magical Papyri, in: idem, Essays on Religion and the Ancient World, Cambridge, Mass. 1972, v. I, p. 188. Luck, Arcana Mundi, p. 27. Huld, Hellenistic Magic and the Synoptic Tradition, p. 31.

${ }^{81}$ John Chrysostom, Commentarius in Acta Apostolorum, Homilia XVI, PG 60, 127 135.

${ }^{82}$ Flavius Josephus, The Jewish Antiquities, VIII. 45. Justin the Martyr, Dialogus cum Tryphone Judaeo, ed. E. J. Goodspeed, Die ältesten Apologeten. Texte mit kurzen Einleitungen. Göttingen 1984 (Impr. $1^{\text {st }}$ ed. 1914), pp. 90-265, 85. 3, p. 197. Leontius 
other patriarchs and prophets, Hebrews were thought of as excellent exorcists and magicians ${ }^{83}$. At one with the above is the attestation of Artapanus that when Moses whispered to the Pharaoh's ear the name of God, he fell dead until Moses brought him back to life ${ }^{84}$. The resurrection of the dead was also a characteristic of the Hebrew prophets ${ }^{85}$ and then of Christ and the Apostles ${ }^{86}$.

The men of the Church were aiming at presenting the Christian holy men as the successors of Moses and the prophets, also in the area of the resurrection of the dead. They claimed that the Christian miracle-workers had received this supernatural power from God himself. On the other hand, all the representatives of the pagan religions and the Jews, who held the same characteristic, were the heirs of the ancient servants of evil and were helped to their work by the demons of darkness. Accordingly, in S. Constantine's life is reported the carrying on of a contest, in front of the Emperor Constantine, between a Christian bishop and a Jew magician. The Jews were for the Christians the most despiteful human nation, faithfuls and descendants of the devil ${ }^{87}$, because they had accused Christ of being

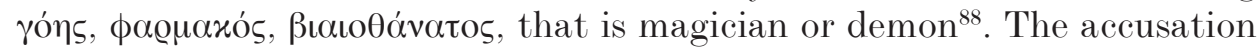

Presbyterus Constantinopolitanus, Homilia X, In Mesopentecosten, ed. C. DAtema - P. Alten, Leontii Presbyteri Constantinopolitani Homiliae (CCSGraeca 17). Turnhout 1987, p. 318, $102-319,113$.

${ }^{83}$ Origène, Contre Celse, ed. M. Bor Ret, t. I (Livres I et II) (SC 132). Paris 1967, 26. Luck, Arcana Mundi, 26. Huld, Hellenistic Magic and the Synoptic Tradition, 31.

${ }^{84}$ Eusèbe de Césarée, La préparation évangélique, IX. 27, 24-25.

${ }^{85}$ Jean Chrysostome, Pour le deuxième jour de la Grande Semaine sur le psaume 5, sur les Actes: "Hommes d'Israel" et sur l'évangile: "Voici l'Agneau de Dieu", 15, 206-220. Idem, Sur le psaume II, sur les Actes: "Or le lendemain leurs chefs se réunirent", et sur le boîteux de la Belle Porte, 2, 31-40. Idem, De patientia, PG 60, 729-738. S. Ephraem Syrus, Sermo in Eliam, 110, p. 220, 437-440.

${ }^{86}$ John Chrysostom, In illud Judaeorum dictum, "daemonium habes"; et in illud, "nolite judicare secundum faciem", $P G 60,763-766$; in illud: "quaecumque ligaveritis super terram, erunt ligata et in caelo"; et de parabola centum ovium, et in dictum evangelistae: "si duo consenserint, etc."; et in illud: "quoties, si peccaverit in me frater meus, dimittam ei", $P G$ 60, 759 .

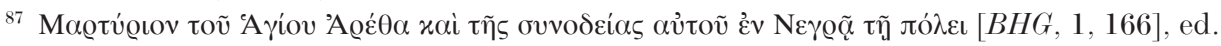
J. F. Boissonade, Anecdota graeca e codibus regiis, v. V. Hildesheim 1962, 2. E. Peters, The Magician, the Witch and the Law. Philadelphia 1978, 12.

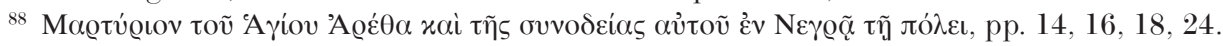
Bıaıod́vato were those, who had died in a violent way; according to the theories of the Chaldeans, the souls of these humans became demons, who played a very important role in magic; see Porphyre, De l'abstinence, t. II (Livres II-III), ed. J. Bouffartigue - M. Patillon, Paris 1979, 47. John Chrysostom, De Lazaro Concio Secunda, PG 48,

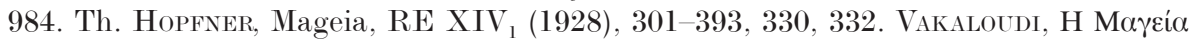

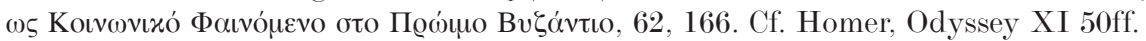


of being a magician was transferred later to the most important representative of his teachings Paul ${ }^{89}$.

In Constantine's time a verbal confrontation between Jews and Christians about the doctrines of the two religions, in Rome, turned out to be a contest of magic between the archbishop Silvestrus and Zambrias, one of the twelve dignitaries of the Jewish community who called themselves

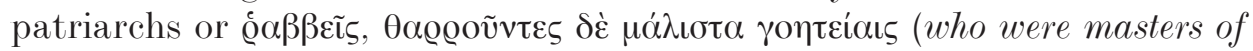
magic ${ }^{90}$.

Based on his magic knowledge the Jew alleged that he knew the name

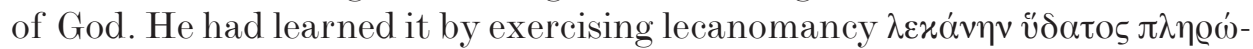

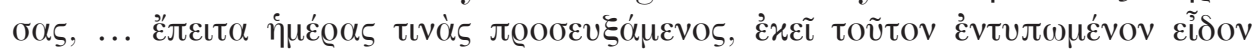

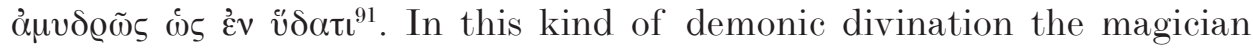
summons the spirits with magical ceremonies over a basin filled with water, and in the reflections on the surface of the water he sees the answers to the questions that he asks ${ }^{92}$. Then the Jew whispered this name to the ear of

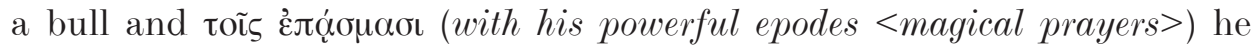
killed it immediately ${ }^{93}$.

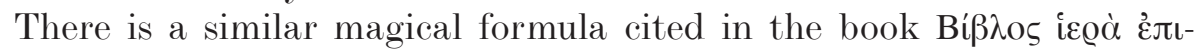

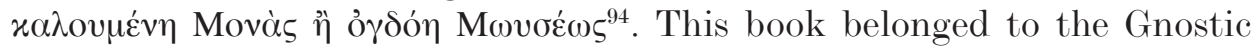
circles of Egypt - who had developed an admixture of Egyptian, Jewish and other mystic elements - in the first Christian centuries. Its purpose was

89 John Chrysostom, In Epistolam ad Ephesios commentarius, cap. IV, Homilia VIII, $P G$ 62, 60. Oecumenius of Trikki, Argumentum in Acta Apostolorum, PG 118, 272A.

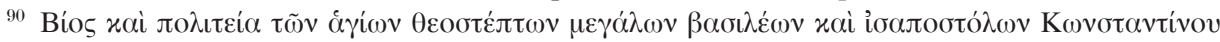

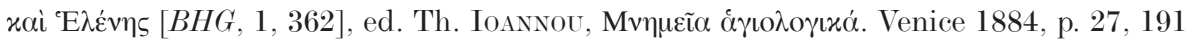
- p. 28, 192. Georgius Monachus, Chronicon, ed. C. DE Boor, corr. P. Wirth, v. 2. Stuttgart 1978, 496, 4-498, 5. Kazhdan, Holy and Unholy Miracle Workers, 78.

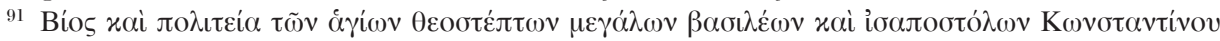

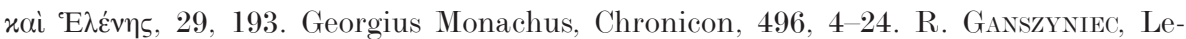
kanomanteia, $R E \mathrm{XII}_{2}$ (1925), 1879-1889, 1883.

92 Hult, Hellenistic Magic and the Synoptic Tradition, 21. For further information about lekanomanteia and other similar kinds of demonic divination, see A. DelatTe, Catoptromancie grecque et ses dérivés. Liège-Paris 1932. Th. Hopfner, Mittel- und neugriechische Lekano-, Lychno-, Katoptro- und Onychomantien, in: Studies Presented to F. Ll. Griffith, Egypt Exploration Society. Oxford, London 1932. A. D. Vakaloudi, Demonic-Mantic Practices. The Implication of the Theurgists and their Power of Sub-

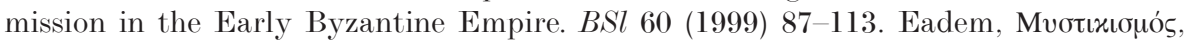

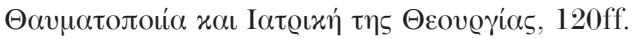

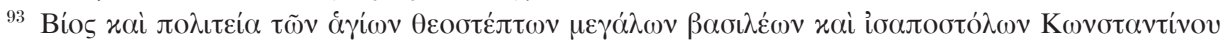
xai ${ }^{~} E \lambda \varepsilon \dot{v} \eta 5, ~ 29,193$. Ed. H. G. OpITz, Die Vita Constantini des Codex Angelicus 22 [BHG 365]. Byz 9 (1934) 6. 550, 13-14. Georgius Monachus, Chronicon, 497.

94 Dieterich, Abraxas. Studien zur Religionsgeschichte des späteren Altertums, in: Festschrift H. Usener. Leipzig 1891, 137. 
to reveal the true, holy, and powerful name of God and to give directions about the magical ceremonies of its use by the magicians ${ }^{95}$. The adept of these ceremonies, by uttering the real name of God, could dominate the demons ${ }^{96}$, could learn the secrets of the universe ${ }^{97}$ and thus obtained complete power over it ${ }^{98}$. The name of Moses gave authenticity to these magical formulae ${ }^{99}$. This book includes a formula in which it is written: "If someone wants to kill every bird, he must whisper to its ear the true, all-powerful name of God, which reveals this papyrus" 100 .

However the Jewish magician didn't possess God's but the devil's name. His knowledge concerned the demons and the invocations of them. The proof of this was given when the Emperor asked him to bring the animal round. This was impossible because the demons wished and aimed at the destruction and death. But when the Christian archbishop Silvestrus invoked the name of Christ, the bull was brought round immediately. That, pointed out the archbishop, was due to the fact that only God can take and give back life ${ }^{101}$.

In the case of Oricatus, he wanted to bring round a woman. The procedure that he followed was: incensing, sprinkling with goat's blood, sacri-

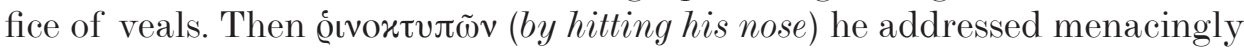

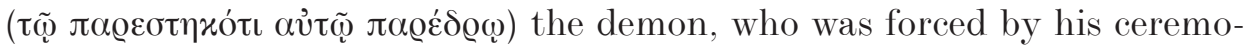
nies to be present and to help him with his work, asking him to resurrect the dead woman ${ }^{102}$. The act of sprinkling with the blood was a symbolic action aiming at giving life to the corps, because blood is the symbol and the power of life.

The fact that he performed the ceremony while hitting his nose very strongly, reminds us of the Greeks' custom to sacrifice to the idols @ivox v-

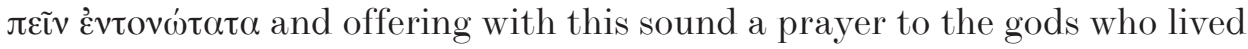

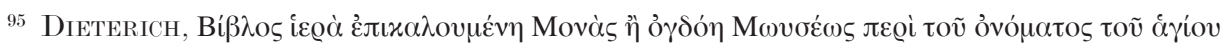
in above, p. 169, $1 \mathrm{ff}$.

96 Preisendanz, PGM. 2: XIII. 795ff.

97 Preisendanz, PGM. 2: XIII. 216.

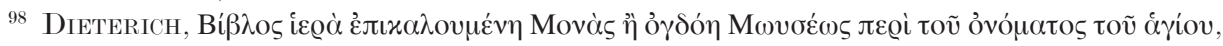
187, 9-13.

99 Hult, Hellenistic Magic and the Synoptic Tradition, p. 33.

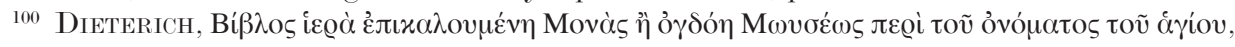
$188,13-14$.

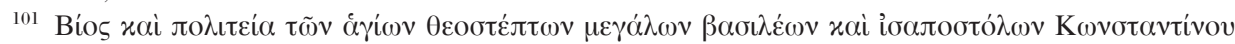
xai ${ }^{\circ} \mathrm{E} \lambda \varepsilon \dot{v} \eta 5,30,193$. Georgius Monachus, Chronicon, 498-499.

102 Anastasius I. Sinaïta, Das sogenannte Religionsgespräch am Hof der Sasaniden, p. 26, 9-15. 
in their statues or icons ${ }^{103}$. Thus, a religious element was used for the

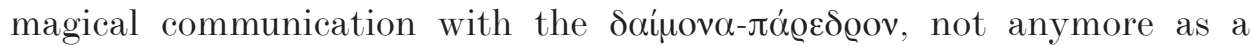
prayer, but as an agent of compelling the demon to obey. Of course the magician had failed once again and the Christian bishops, by invoking the name of God, accomplished to bring the woman round ${ }^{104}$.

John Chrysostom gives a very interesting information about resurrection of the dead. The magicians had the ability of the apparent death, that is to pretend a fictitious death, to be buried and to give the impression that they have been resurrected. In fact, said Chrysostom, with some magical ceremonies they achieved to deceive people's vision, to pretend that they were dead and with their false resurrection to mislead people toward the doctrines of Satan. These were the false prophets, the false Apostles, the false "Christs" who were sent to compete the real ones ${ }^{105}$.

At this point I would like to remind of the sceptic of all the mystic religions at this age. The sources described their cults by citing that the faithfuls who attended their ceremonies and especially those who conducted them, managed to separate their soul from their body and, with the psychopomp Hermes as a guide ${ }^{106}$, descended to Hades, where they subdued its demons ${ }^{107}$. Then they learned the secrets of the seven cosmic zones ${ }^{108}$ and thus they were able to rule the universe ${ }^{109}$. Therefore, maybe the false death of these people, to whom Chrysostom refers, is just the practice of these cults.

If one studies the similar practices of the ancient Jews, then one can trace the influence, which these practices had exercised on the corresponding Byzantine magical rituals ${ }^{110}$.

Another contest between Christian and pagan priests consisted in remaining in a flaming kiln or a big fire. Probably we can trace here, once again, a connection with the ancient Jewish miracle-workers and parti-

103 Sophronius Monachus Sophista, Los "Thaumata de Sofronio", ed. N. F. Marcos, Contribution al estudio de la "Incubatio cristiana" (Manuales y Anejos de "Emerita" 31). Madrid 1975, XXXI. 1-7 (pp. 306-308).

${ }^{104}$ Anastasius I. Sinaïta, Das sogenannte Religionsgespräch am Hof der Sasaniden, p. 26, $14-29$.

${ }^{105}$ John Chrysostom, De divite et Lazaro Concio Quarta, $P G 48,1010$.

106 Preisendanz, PGM. 2: XIII. 523-525.

107 Preisendanz, PGM. 2: XIII. 795ff.

108 Preisendanz, PGM. 2: XIII. 216.

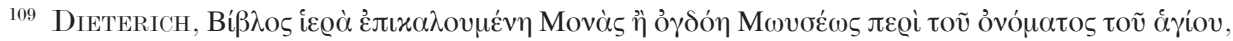
$187,9-13$.

110 For similar ancient Jewish practices, see M. D. Swartz, Scholastic Magic, Ritual and Revelation in Early Jewish Mysticism. Princeton, N. J. 1996, pp. 8, 48-50, 153-154. 


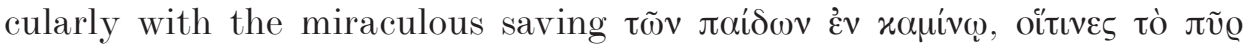

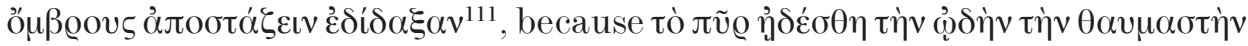

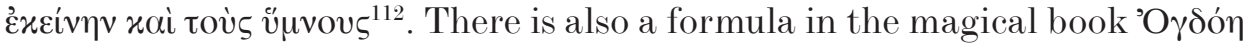

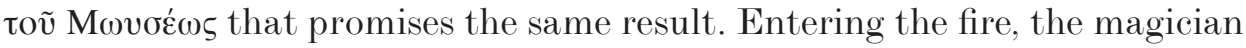
must recite: "to quench the fire; 'Tisten to me fire, work of God's will, glory of the honest leading light, quench, become snow. because this is the Aion ${ }^{113}$ that gets upon the immaculate fire, to be disbanded from me every flame, every power of the essence with the command of the one that always exists, don't harm me fire, don't eat my flesh because I am - say the name ${ }^{114 " 115}$.

Oricatus made this attempt, but he failed and was almost burnt alive, whereas his Christian opponent walked out without any harm ${ }^{116}$. Oricatus came out between life and death, but the Christian bishops cured him with the invocation of Christ's name. The king ordered his crucifixion, but the bishop Aphrodisianus saved him, showing to everyone that the Christian motives were unselfish ${ }^{117}$.

Another similar contest is related with a confrontation between a Christian monk and a Manichean ${ }^{118}$. Saint Copres, who lived during the reign of

111 Jean Chrysostome, Pour le deuxième jour de la Grande Semaine sur le psaume 5, sur les Actes: "Hommes d'Israel" et sur l'évangile: "Voici l'Agneau de Dieu", 15, 206-220. Idem, Sur le psaume II, sur les Actes: "Or le lendemain leurs chefs se réunirent", et sur le boîteux de la Belle Porte, 2, 31-40. Idem, Homilia habita in martyrio sive in ecclesia, quae est in antiqua seu vetere petra, ubi pauci ob delapsam pluviam convenerant: quod frequenter convenientum sit; neque oporteat eos qui in peccatis sunt de salute desperare sed poenitentiam exhibere, $P G$ 63, 469-470. Cosmas of Jerusalem, Ad Carmina S. Gregorii Theologi, 350 .

112 John Chrysostom, In Epistolam ad Ephesios commentarius, cap. IV, Homilia VIII, $P G 62,67$.

113 A very common god of the Gnostics.

114 He means the name of God.

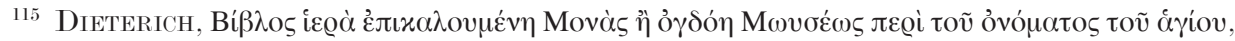
$191,3-9$.

${ }^{116}$ Anastasius I. Sinaïta, Das sogenannte Religionsgespräch am Hof der Sasaniden, p. 27, $4-11$.

117 Ibidem, p. 27, 15-23.

118 Manichaism was a gnostic sect which had adopted the Persian magical religion that was attributed to Zoroaster. The Christians hated the Manichaeans because they had converted many people to their beliefs; see Epistulae Pseudo-Ignatii, (Ad Philippienses, De baptismo), ed. F. X. Funk, Patres Apostolici, v. II. Tubingae 1901, 110, IV, 3. Théodore de Mopsueste, Homélie II $^{\mathrm{e}}$ sur le baptême (= Hom. XIII), Les homélies catéchétiques de Théodore de Mopsueste, reproduction phototypique du MS. Mingana Syr. 561 (Selly Oak Colleges' Library, Birmimgham), ed. R. Tonneau - R. Devreesse (StT 145). Città del Vaticano 1949, II. § 10, p. 385. For some further information about Manichaeism, see P. BRown, The Diffusion of Manichaeism in the Roman Empire. Journal of Roman

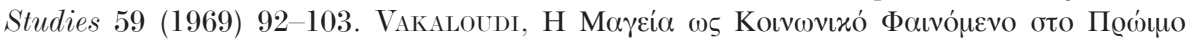


Julian, challenged the heretic to get into a big fire at the center of the town's square. The one who would not be burnt, would prove also the credibility of his belief. The saint got first into the fire, making the mark of the cross, and remained in the flames for half an hour without having any problem. Then the people dragged violently the Manichean into the fire, while he resisted, and there he was burnt as a deceiver ${ }^{119}$.

By everything that was written, it was pointed that the Christian hagiography was bent on proving that the Christian saints were the successors of the ancient Jewish holy miracle-workers, who were endowed with miraculous power directly from God. Then the Christian writers tried to prove that their holy men used this miraculous power exactly as the ancient Jews had used it against their greatest pagan enemies, in order to prove their God superior to any other. Practically, all these miraculous achievements were based on a perception which had its roots in the Hellenistic age and had been developed during the Christian centuries. This perception alleged that powerful "Philosopher-magicians" existed, who were studying the supernatural forces and because of this knowledge achieved to control them. By this means, these men, called either magicians or miracle workers, had the acquiescence of the spirits, and through them of God himself, to control their corresponding cosmic elements as they wished. This perception has been developed by the Christian writers in order to show their saints as holy miracle-workers, blessed by God and his angels to be able to do wonders, while their pagan opponents were impious magicians (followers of the black arts) who were acting with the help of the evil demons.

Bv̧óvtı, 309-314. Eadem, Religion and Magic in Syria and Wider Orient in the Early Byzantine Period. BF 26 (2000) 255-280, pp. 264-270.

119 Copres [BHG 2083], Timotheus, Historia monachorum in Aegypto, ed. A. J. Festugière, Edition critique du texte et traduction annotée (Subsidia Hagiographica 53). Bruxelles 1971, 30. 87, $190-32.88,207$. 
